\title{
Editorial
}

\section{Unequal Treatment}

\author{
J. David B. Oliver, Coopers \& Lybrand, London
}

If a non-resident company enjoys an exemption from tax which is not available to resident companies, is it entitled to interest on the resulting tax repayment when the domestic law provides that no interest on tax repayments may be paid to non-residents? In making that claim Commerzbank relied on the non-discrimination article in the UK/German treaty and on the provisions of Article 52 and 58 of the Treaty of Rome. Although it failed in the UK courts in its arguments based on the UK/German treaty the submission on the Treaty of Rome was referred to the European Court of Justice which has now ruled in favour of the bank.

The decision is an important step forward in the role of the Rome Treaty in matters of discrimination. This is particularly so because the bi-lateral treaty did not provide the taxpayer with relief.

The judgment of the European Court is very brief, but that was because the point, as the Court viewed it, was a very short one. The national provision clearly entailed unequal treatment. The fact that in this particular case the exemption from taxation on income which gave rise to the refund was only available to non-resident companies did not justify such a general provision which was therefore discriminatory.

Since the interest in question would have been paid to the taxpayer to compensate for the loss of the use of his money one can readily see why the European Court refused to look at the result in its wider context. The claim was for interest rather than a further tax refund, and indeed that was one reason for the failure of the arguments based on the UK/German treaty. In that way the case contrasts with the Bachmann decision where the European Court justified its decision against the taxpayer on the grounds of the requirement to maintain the coherence of the national tax system. Commerzbank was a bad case on which to test this point because, to repeat, it concerned interest and not tax.

The decision nevertheless opens up some intriguing questions for taxpayers in EC states and the Rome Treaty could provide, as in Commerzbank, a useful alternative ground for challenging discrimination especially since the ruling on the Rome Treaty will ultimately come from the European Court rather than the national court.

Does this mean that, say, provisions which require resident companies to be owned by a resident company to qualify for fiscal unity may be found to be discriminatory? Indeed they may be found to be discriminatory already under bi-lateral treaty provisions but some EC states would dispute that.

Can a branch and a resident company under common control form a fiscal unity? What is to be the appropriate treatment of dividends or interest paid by a resident company to such a branch? Other rules involving reorganisations and de-mergers may make distinctions between resident and non-resident companies. How far are these justified by the need for coherence of the tax system and how far are they discriminatory? How far should the overall result be looked at and how far should the possibly more favourable position of a non-resident taxpayer be taken into account in deciding whether the provision complained of broadly amounts to unequal treatment?

It has been suggested that to reduce withholding tax rates or to grant imputation credit refunds by bi-lateral treaty for some EC states but not others is discriminatory. Since such rates are usually reduced on the basis of reciprocity this suggestion, if not in the realms of fantasy, would be a nasty shock to any EC states which had some treaties with zero and some with positive withholding rates. This line of argument would reduce the positive rates to zero without necessarily altering the reciprocal rates of the other EC state.

An intriguing possibility in all of this is that a resident in a non-EC state wishing to conduct business through a branch in an EC state will find that if he conducts the operations directly he will only be able to rely on the bi-lateral treaty provisions (if any). If instead he forms a company in another EC state and conducts the operations in the first EC state through a 
branch of that company then that company will be able to invoke the Treaty of Rome in relation to any discriminatory features in the taxation of the branch operations.

The situation seems likely to develop on a case by case basis as the European Court applies either the 'coherence of the tax system' test (which itself can be criticised) or an overall result test to the facts of each case. 